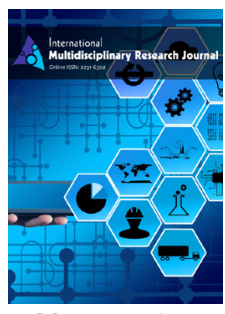

ISSN: 2231-6302

\title{
A comprehensive review of ethnobotanical plants used by the people of Pir Panjal Range in (Jammu Division) Union Territory Himalaya of Jammu and Kashmir- India
}

\author{
Tahir Mahmood* \\ Centre for Biodiversity Studies, Baba Ghulam Shah Badshah University Rajouri 185234
}

\begin{abstract}
A B S T A C T
The current paper provides a taxonomic inventory of the medicinal plant species collected by the author during the last one decade from Pir Panjal range in (Jammu Division) Himalaya of Union territory Jammu \& Kashmir- India. The inventory records a total no of 76 medicinal species belonging to 45 families of the total taxa were recorded for the medicinal Purposes. The inventory is expected to provide baseline scientific data for further studies on plant diversity in Jammu division and can be used to facilitate the long-term conservation and sustainable use of medicinal plant resources in the Himalaya region, and among all the families Cucurbitaceae and Euphorbiaceae were found to be most dominant families in term of the species in the areas with 06 species, followed by Polygonaceae and Rosaceae.
\end{abstract}

Tahir Mahmood

Email: tahirchoudhary786@

gmail.com

KEYWORDS: Ethnobotanical, Medicinal Plants, Jammu division, Pir Panjal, Himalaya, J\&K-India

\section{INTRODUCTION}

Plants are remarkable source of valuable substances for human beings. These are showing variation in their habitat as well as their habit. As per climatic condition, the plants are showing their presence in different sites. Plants are essential for healthier life because they provide us medicines, which are both effective and safe, without any side effect. Some pathological conditions in human being that could not be fully treated by conventional pharmaceutical are numerous [1] for this reason, there is a growing tendency in use of herbal preparations. The world health organization (WHO) estimates that $80 \%$ of the world population depends on plants remedies for its primary health care needs [2]. The local peoples of the rural areas have good knowledge about the uses of plants and they prefer medicinal plants due to their easy availability and cheap therapy as compared to costly pharmaceuticals. The traditional Practioners are playing an important role in providing health coverage to $75 \%$ of the population residing in villages and rural areas. Maximum 76\% rural peoples depend on forest products for fulfilling their daily needs. India ethnobotanical work has been done in the past [3-5]. while in all these studies qualitative approaches have been adapted to document ethnobotanical information [6]. Ethnobotany of Jammu division Union territory, Jammu \& Kashmir is getting various studies have been reported from various parts of the areas [7-15]. While in contrast, ethnobotanical research has been somewhat neglected in the south foot hilly areas of district rajouri province Jammu particularly. In province Jammu, few studies were carried out my some Scholars and Scientists in the past [16] conducted research Flora of Jammu and Plants of Neighborhood Bishen, Flora of upper Liddar Valleys of Kashmir Himalaya. Ethnobotanical study of useful climbers creepers and twiners of Baba Ghulam Shah Badshah University campus and adjoining areas of district rajouri Jammu and Kashmir [10]. Ethnobotany of medicinal plants in district Mastung of Balochistan province -Pakistan [17]. The present study can be considered as the first time and one which deals with an ethnobotanical study on medicinal plants in this region. Jammu division has also got importance for its topography as well, inside having high mountains, with desert habitats and having high rich diversity of medicinal plants. The rural areas of the Jammu division still depend on these wild plants for cure the disease and having a good ethnobotanical knowledge about medicinal plants. but currently the ethnobotanical knowledge is disappearing very fast from the urban areas of the Jammu division because of being closer to and bounded with the capital city of province Jammu' having health and other facilities. 
The aim of the current research is to highlight the key of medicinal plants in Jammu division of Pir Panjal range Himalaya of Union territory Jammu \& Kashmir- India.

The aim of this study was to document ethnomedicinal uses of plants and analyzed ethnobotanical information using quantitative indices of information consent factor (ICF), fidelity level (FL), use value (UV), use report(UR) frequency citation (FC) and relative frequency citation (RFC).

\section{MATERIAL AND METHODS}

\section{Jammu Division Geo-ethnographical Overview}

Jammu division has an area of $26.64 \mathrm{~km}^{2}$ with ten districts. Jammu, Doda, Kathua, Ramban, Reasi, Kishtwar, Poonch, Rajouri, Udhampur and Samba, Union territory: Jammu and Kashmir (Figure 1). According to the census 2011, the total population of Jammu Division is 5,350,811. Its lie between... 18', East longitude and 32 degree $50^{\prime}$ and 33 degree $30^{\prime}$ North latitude. The Jammu division presents a composite culture Pahari, Gojri, Dogri and Kashmiri. Irrespective of ethnic groups all speak the pahari language with easily. The climate varies from semitropical in the sourthen part to temperate in the mountanious northen part. The sub-tropical region receives regular monsoons whereas the northen part prone to hailstorms experiences excessive rains. The Jammu division is drainded by small and big rivers. Some of the tribal peoples annually migrate during winter from higher altitudes to lower, During the summer from lower to higher altitudes with their families along with Cattles ( Sheeps, Goats, Horses etc.,) Migration to other countries is $14.9 \%$ for their bread and butter of all migrants. Migration starts in April ending and continues till June. The migrants return from September and continue till November.

\section{Socio-economic Condition of the Area}

Jammu division is the major earning means of the peoples in the region. Nearly $57 \%$ of the population of Jammu division depends on agricultures. Important cultivated plants are wheat, maize, potato, onion, and other vegetables. Some of the local inhabitants collect medicinal plants from forests, deserts, mountains and plains and sell them to the local traditional herbs sellers in very cheap prices. Local traditional herbs sellers then supply these plants to the pharmaceutical companies in good prices. The Jammu division has been released with diverse flora included a great numbers of medicinal plants. The rural areas of the division are still dependent on medicinal plants for their health care because of lack health centers in the area. If the sustainable use of wild flora and cultivation of medicinal plants are promoted in the area, this will strongly affect on the socio-economic condition of the local inhabitants.

\section{Field Interviews}

For the study and documentation of medicinal plants, intensive exploration trips were conducted about twelve months from January 2019 to February 2020. The questionnaire was mainly focused on the ethnobotanical claims and traditional believes of local communities and nearby peoples. The interviews were conducted using the local languages that are Phari, Gojri, Urdu, as the first author is a local person of the region. for the ethnobotanical information, a total no 197 inhabitants of the area were interviewed. 86 women, 99 men, and 12, traditional healers were interviewed. The informants were divided into three different age of groups i.e. 22-42-43-63-64-84- years old. All the informal meetings were held 26 different villages of the district rajouri province Jammu i.e. Kurhad, Prori, darhal, Khoriwalli, Palma, Bakori, Budhal, Soaker. Saj. DK, Dodaj, Rehan, Hobby, Kandi, Jari-wali, Basholi. Udhampur. Reasi.

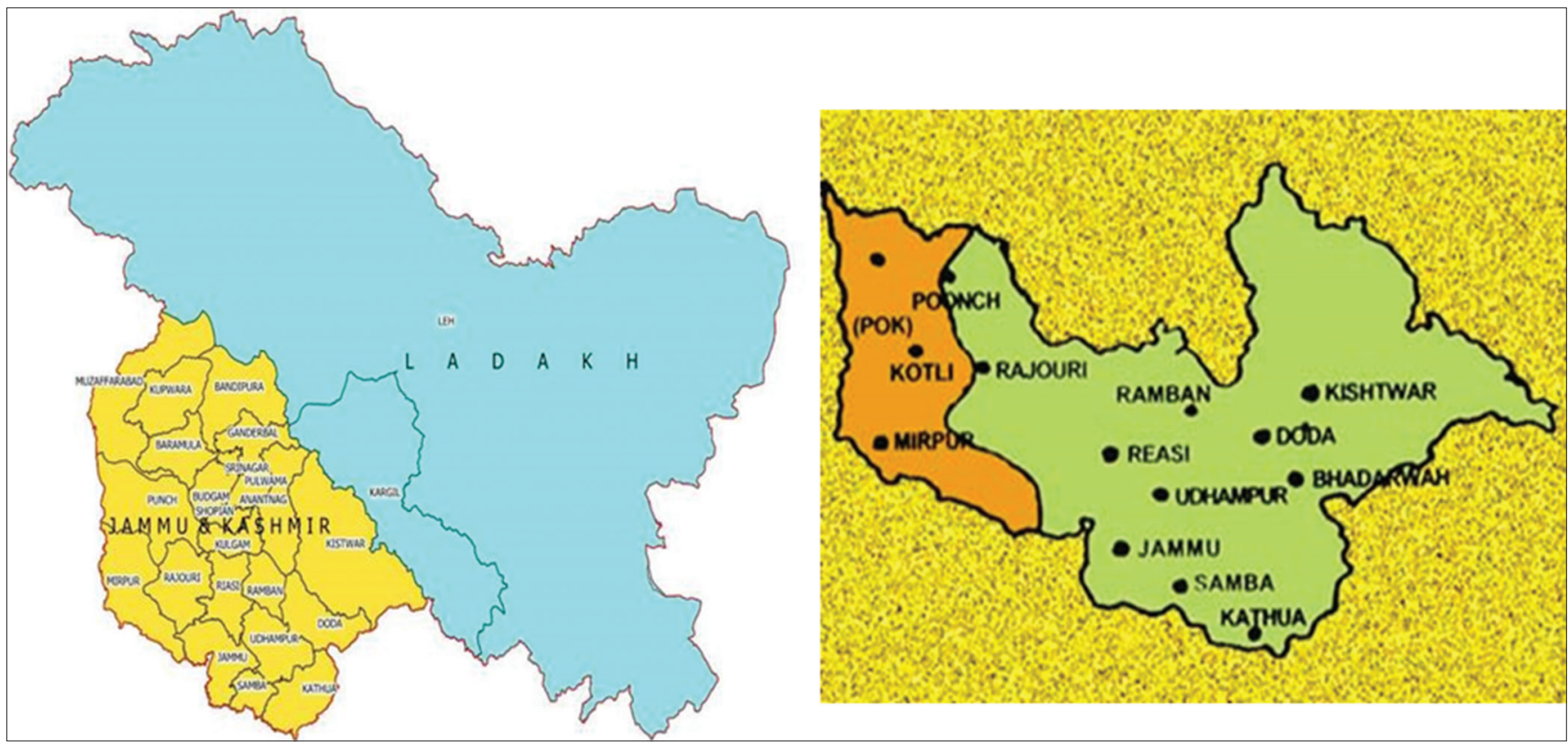

Figure 1: Map of India showing Union Territory Jammu, Kashmir Ladakh. Map showing Jammu division Union territory of Jammu \& Kashmir, India 


\section{Collection, Identification and Deposition of Medicinal Plants}

The plants were collected during twelve months (January-2019to Faburary-2020). The Jammu division covering almost all the seasons of the year and from all the parts of districts. The collected plants specimens were dired and preserved processed as per routine herbarium techniques recommended by Jain and Rao [18] for reconfirmation of plants identification, the flora of Flowers of the Himalaya [19]. Exotic Ornamental Flora of Kashmir [20] Flora of British India [21] and Flora of Jammu and Kashmir. Vouchers specimens were deposited in the herbarium, Centre for Biodiversity Baba Ghulam Shah Badshah University rajouri for futures references.

\section{Quantitative Analysis of Ethnobotanical Results}

The data collected was analysis using quantitative value indices.

\section{Information consensus factor (ICF)}

Information consensus factor (ICF) was obtained [22] using the following formula;

$$
\operatorname{ICF}_{=}\left(\mathrm{N}_{\mathrm{ur}}-\mathrm{N}_{\mathrm{t}}\right) /\left(\mathrm{N}_{\mathrm{ur}}-1\right)
$$

Where $\mathrm{N}_{\text {ur }}$ refers to the total number of uses reports for each disease category and $N_{t}$ it is the number of taxa used in that category. It used to test the homogeneity of knowledge on the uses of species in the illness categories between the populations. The ICF provides a range of (0-1). High ICF shows that there is a narrow well-defined group of species used to cure a particular ailment category and/or that information is exchanged between informants and low ICF values (close to zero) indicate that informants disagree over which plant to use due to random choosing or lack of exchange of information about the use among informants [23].

\section{Fidelity level (FL)}

Fidelity level (FL) index was calculated by using the following formula as described by Friedman et al. [24] to determine the most preferred species used in the treatment in the same category:

$$
F L\left(N_{P} / N 100\right)
$$

Where $\mathrm{N}_{\mathrm{p}}$ is the number of informants citing the use of the plant for a particular illness and $\mathrm{N}$ is the total numbers of informants citing the species for any illness. High FL value indicates high frequency of use of the plant species for treating a particular ailment category by the informants of the study area.

Frequency citation (FC) and relative frequency citation (RFC)

The FC of the species of plants being utilized was evaluated using the formula: $\mathrm{FC}=$ (Number of times a particular species was mentioned/ total number of times that all the species were mentioned) 100 and the relative frequency citation (RFC) index by using the following formula:

$$
\text { RFC FC /N (0 RFC 1) }
$$

The index is obtained by dividing the number of informants mentioning a useful species FC or frequency of citation by the total number of informants in the survey $(\mathrm{N})$. RFC value varies from 0 (when nobody refers to plants as a useful one). to 1 (when all the informants mention it as useful). RFC index, which does not consider the use-category (UR or use-report it is a single record for use of a plant mentioned by an individual).

Use value (UV) and use report (UR)

$$
\mathrm{UV} \Sigma^{\mathrm{U} / \mathrm{n}}
$$

Where UV is the use value of a species, ' $U$ ' is the number of use reports cited by each informants for a given plant species and ' $n$ ' is the total number of informants interviewed for a given plant. The UV is applied in determining the plants with the highest use (most frequently indicated) in the treatment of an ailment, while use report (UR) is the use recorded for every species,

\section{RESULTS AND DISCUSSION}

\section{Use of Plants and Demography}

A total no of 197 inhabitants of the Jammu division (40\%) women, (30\%) men and $(09 \%)$ men traditional healers of different age of groups were interviewed. The informants were divided into three different ages of groups. Most of the informants above belonged to the age of 60 year (Fig.2) and many informants were categorized (Table 1) in total 45 families and 76 species with local name of the plants, family

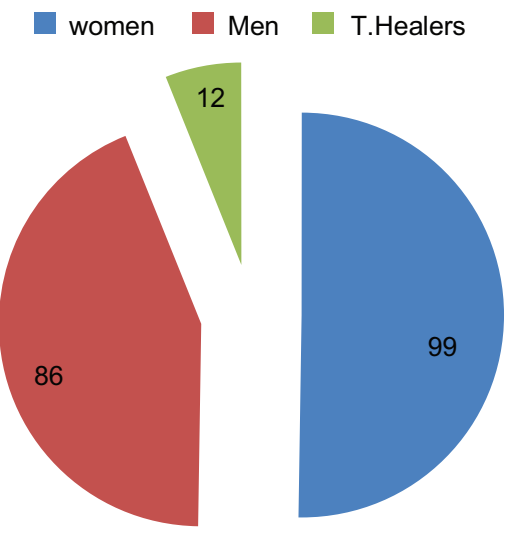

Table 1: All informants are categorized

\begin{tabular}{llc}
\hline S.no & Category & No of peoples Interviewed \\
\hline 1. & Men & 86 \\
2. & Women & 99 \\
3. & Traditional healers & 12 \\
Total & & 197 \\
\hline
\end{tabular}




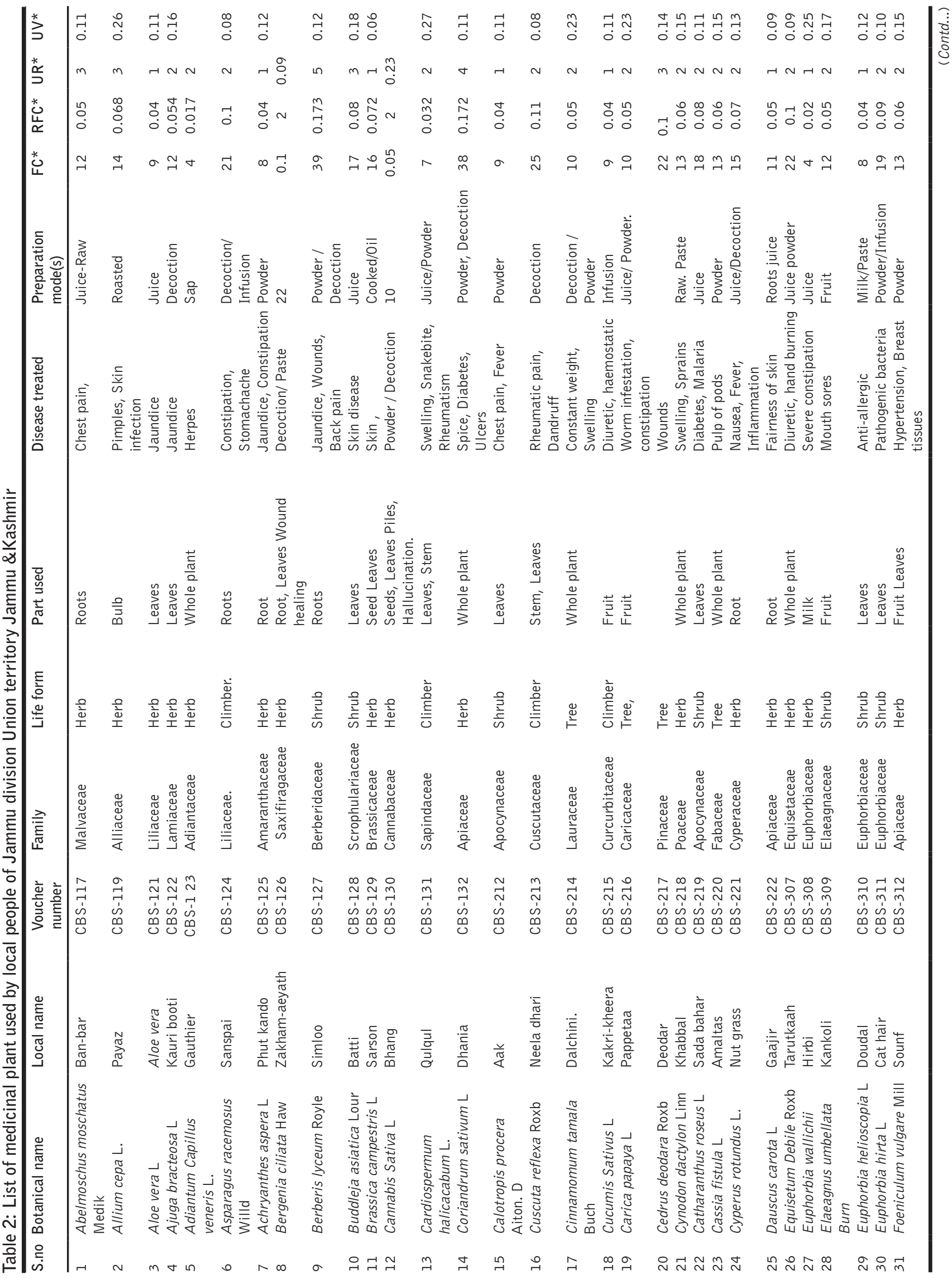


\begin{tabular}{|l|l|l|l}
\hline \\
5
\end{tabular}

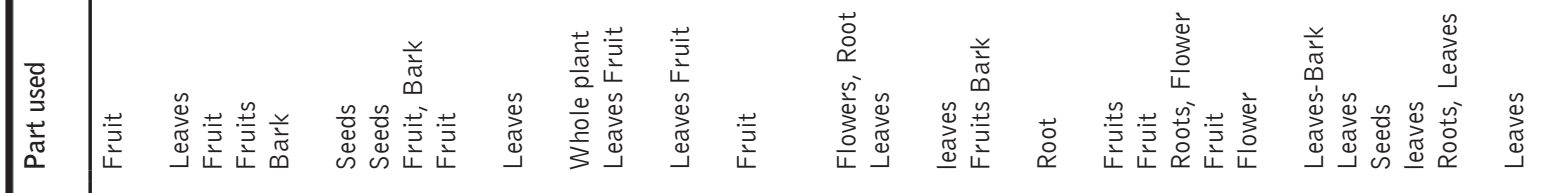

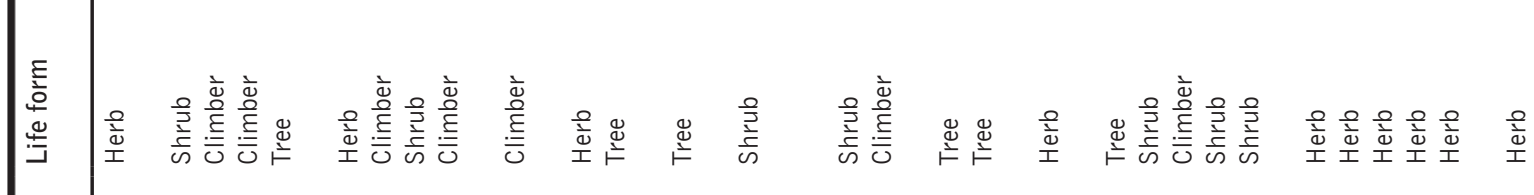

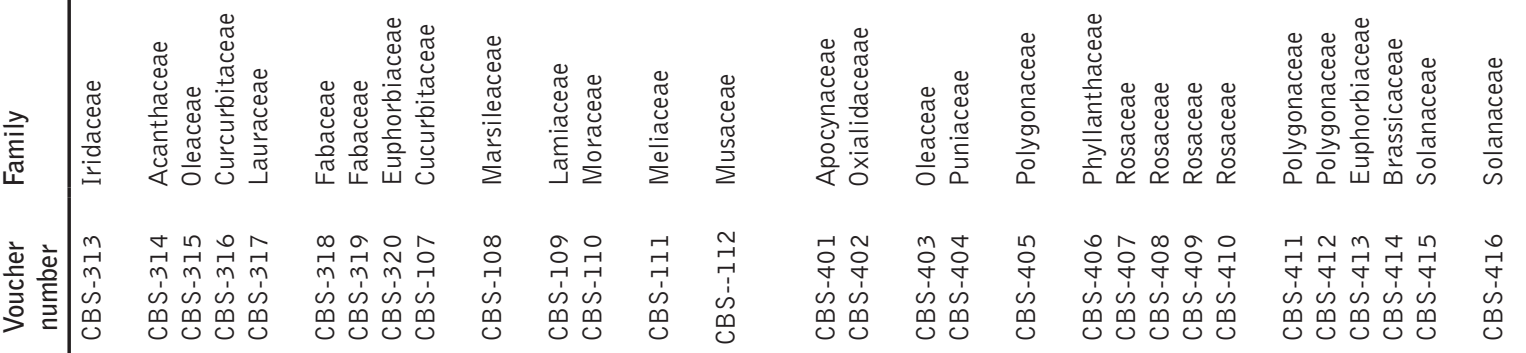

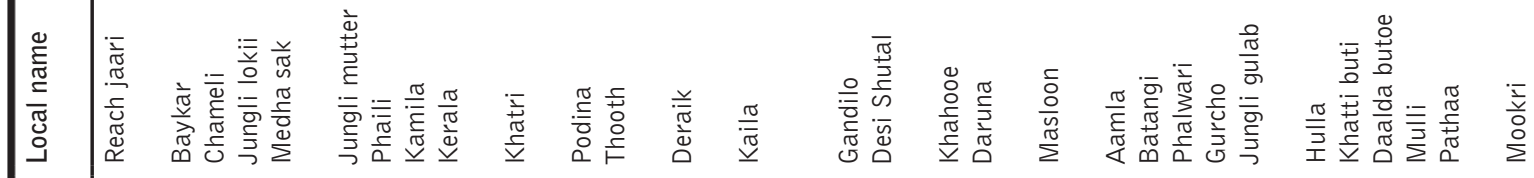

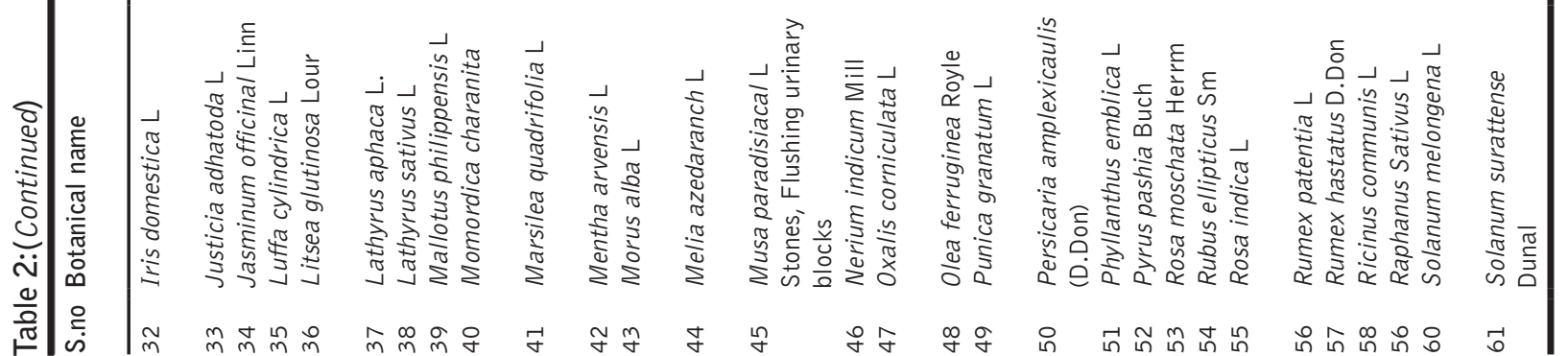




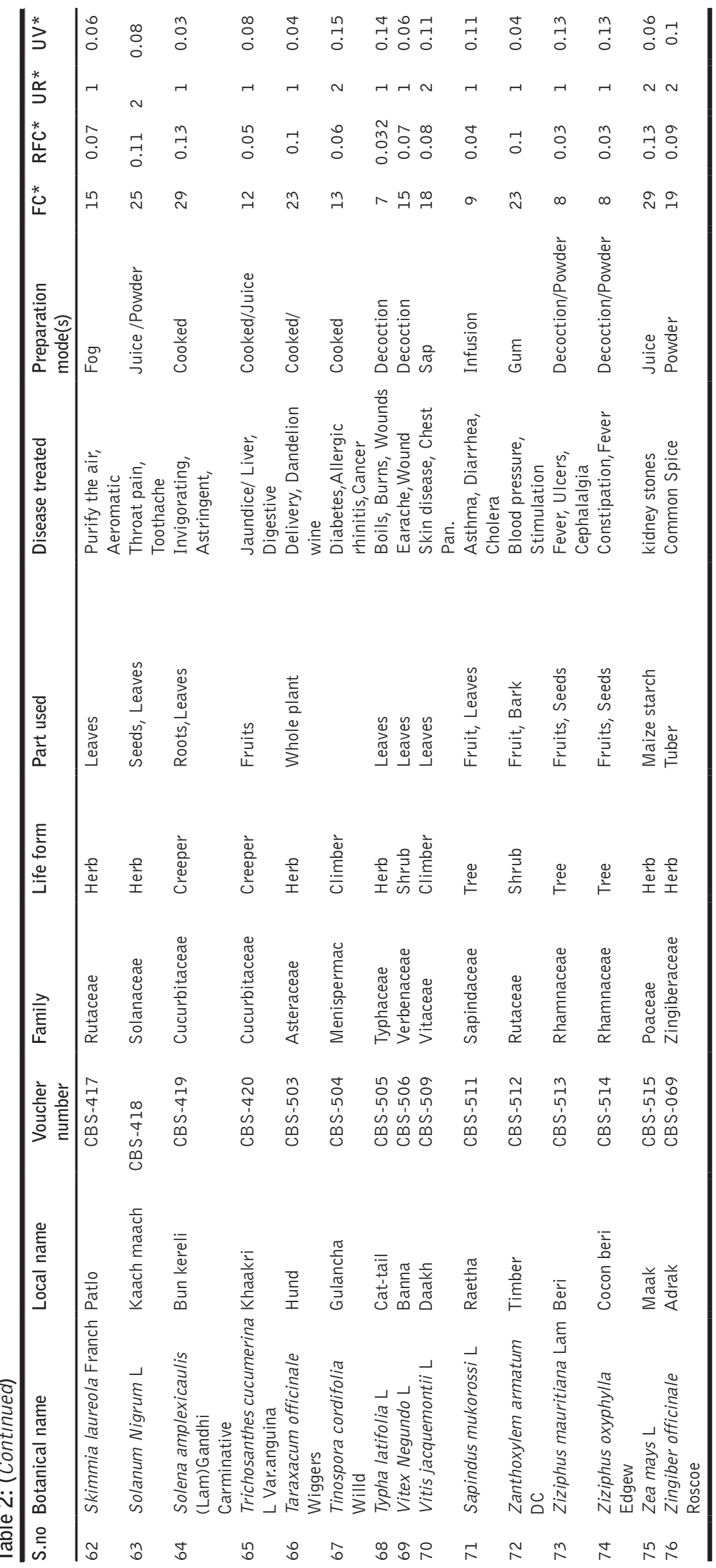




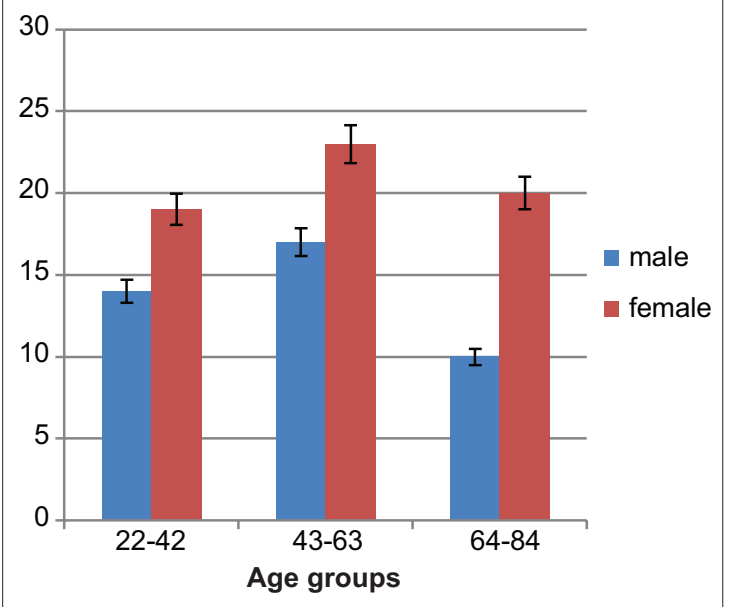

Figure 2: Distribution of gender, age and number of informants interviewed

name their uses and parts of the plants used for their medicinal values, use repot(UR) use value, (UV) frequency citation (FC) and relative frequency citation (RFC) are listed in Table 2.The best represented used families in terms of the number of species are cucurbitaceae (6 species), Euphorbiaceae, Rosaceae, Polygonaceae, Apiaceae, Apocynaceae, with 7 species each (Table 3) the most common part of the plants used are their leaves and whole plant (19\%) each (Fig. 3) plant are often used as decoction $(29 \%)$ and a small portion is also used roasted, juice and soups. Highest plants species are used in the treatment of gastrointestinal disease (21 species) Moreover a single plant is used for the more than one disease for example, Mentha arvensis (Stomach pain) Luffa cylindrica (Diuretic, Splenopathy) Zanthoxylem armatum (Blood pressure, Stimulation) Berberis lyceum Royle (Jaundice, Wounds, Back pain) Highest ICF value (1) was recorded for antidote category. $100 \%$ fidelity level was found for four plant species i.e. Zea mays, Pyrus pashia, Musa paradisiacal, and Momordica charanita. The highest use value was reported for the Litsea glutinosa (0.6). Highest RFC value was calculated for Berberis lyceum, Coriandrum sativum, (0.23). and other five uses reports for each in Table 3.

The results of the study showed that Cucurbitaceae is the largest medicinal plant family. The values and characteristics of family, Curcurbitaceae as a Predominant in this area, among all the families Cucurbitaceae and Euphorbiaceae were found to be most dominant families in term of the species in the area with 06 species, followed by Polygonaceae and Rosaceae.

\section{Herbal Drug Preparation Method}

Among herbal drug preparation, decoction (21\%) with 29 species). And infusion (17\% with 28 species) (Fig. 3 ) are highly used in the area.

The result of wide spread use of decoction and infusion agree with the results of Gurdal and Kultur [25] and Ahmed et al. [26] who reported that decoction was the most commonly used

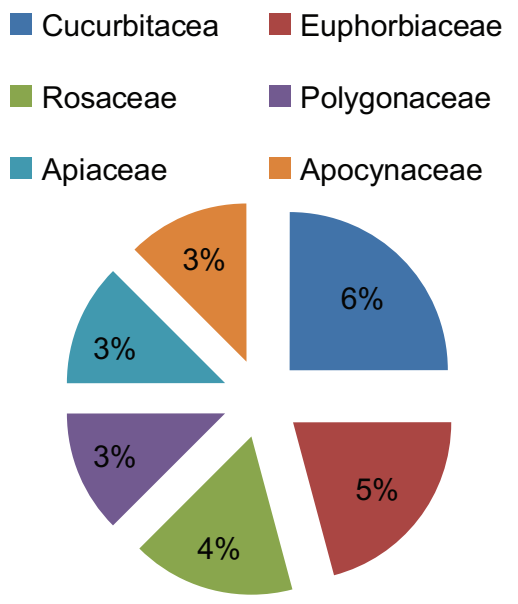

Table: 3 Most used families of the study area

\begin{tabular}{lc}
\hline Family name & Number of taxa \\
\hline Cucurbitaceae & 6 \\
Euphorbiaceae & 5 \\
Rosaceae & 4 \\
Polygonaceae & 3 \\
Apiaceae & 3 \\
Apocynaceae & 3 \\
Total & 24 \\
\hline
\end{tabular}

preparation method. Followed by infusion. In the study eight internal application methods were recorded i.e. decoction, infusion, powder, raw, cooked, tea, soup and juice have been used internally. The gum was used as chewing gum and 4 direct external application methods like milk/sap, steam, smoke, and roasted were also recorded.

\section{Plant Part used for Medicinal Purposes and their Life Form}

Among the different parts of the plants used in therapy, the whole plant and leaves are used frequently (21\% of each) (Fig 4). In literature, it was also noted that the leaves are more accessible or available in nature and are relatively more abundant as compared to other plant parts which may explain why they are used, while the frequent use of whole plant in the region may be that the area is mountainous and very less rain falls in the region, mostly plants are herbaceous and wild bushes (Fig. 5.) due to this the people collect the aerial part of the plants and use their decoction and infusion commonly. The herbaceous habit is not only dominant life form in our study but it is a common and widespread ecological phenomenon around the world. That for the preparation of remedies from the whole plants is very commonly used (23.13\%) followed by leaves (19.28\%). It is also noticed, that if only one plant part is required e.g. leaf, flower or fruit for the need is local people collects the whole plants instead of single part, the practice of plant parts collections has adversely affected the population size. The other plants used by the local people were seeds (20\%), fruits (10\%) and other (Fig. 4) due to extensive use of seeds and whole plant, The pressure on the survival of such wild populations has increased. The least 
used parts are tuber and roots, probably due to their low level of approach that very few plants have tubers in the area and the roots of shrub and tree are very difficult to get.

\section{Quantitative Analysis}

Informants consensus factor (ICF) and fidelity level (FL)

The informant consensus factor (ICF) of medicinal plants in our study ranges from (0-1.0) (Table 4). Antidote category has highest ICF Value (1.0) in which only one species Calotropis procera is used for snake bite and scorpion stung. The second highest value observed is for respiratory disease $(0.39)$. the least agreement between the informants was observed for plants used for nose, ear and throat disease ( ENT) (Earache, throat inflammation) and eye disease both having the zero ICF. Similar result were reported by Jamila and Mostafa [27], who reported the second highest ICF for respiratory disease (ICF: 0.81) and least ICF for eye and vision problems (ICF: 0.21). Fidelity level (FL) of 21 plant species was found against a given ailment category (Table 5) 100\% fidelity level was calculated for three plant species. According to our findings, we suggest that high FL indicates the prevalence of specific disease in the area that are treated with the medicinal plants with the high FL values.

\section{Threats to Medicinal Plants and Indigenous Knowledge in the Area}

Majority of the people of the areas are educated but especially in the rural areas are $56 \%$ illiterate of the division and the earning sources of the locals are only agriculture and livestock. Some of the local inhabitants collect medicinal plants-- Momordica charanita, Punica granatum, Phyllanthus emblica, Raphanus Sativus, Zanthoxylem armatum, Zingiber officinale Mentha arvensis, Litsea glutinosa, Lathyrus aphaca and sell them to the local herb sellers in very cheap prices and these species are traded to the pharmaceutical companies in good prices. Over grazing point, urbanization, and uprooting of medicinal plants and serious threat in the areas, These threat increase the risk of their extinction and calls for a strict control over their protection by the authorities. The sustainable use of wild flora for cultivation of medicinal plants should be promoted in the area, This will strongly improve the socioeconomic condition of the local inhabitants.

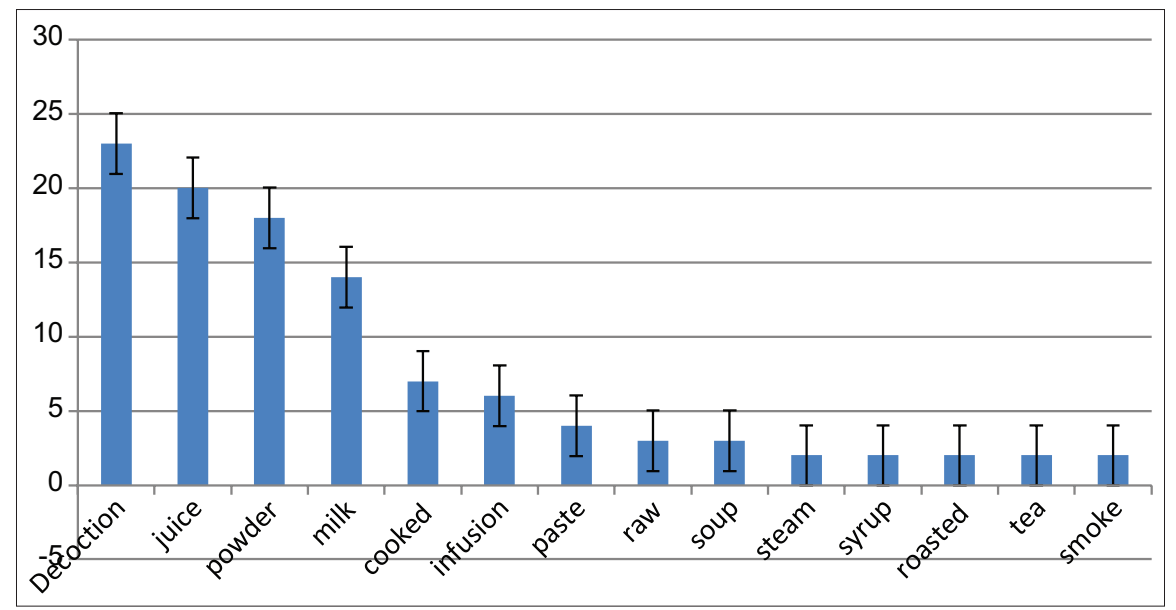

Figure 3: Percentage of herbal drug preparation

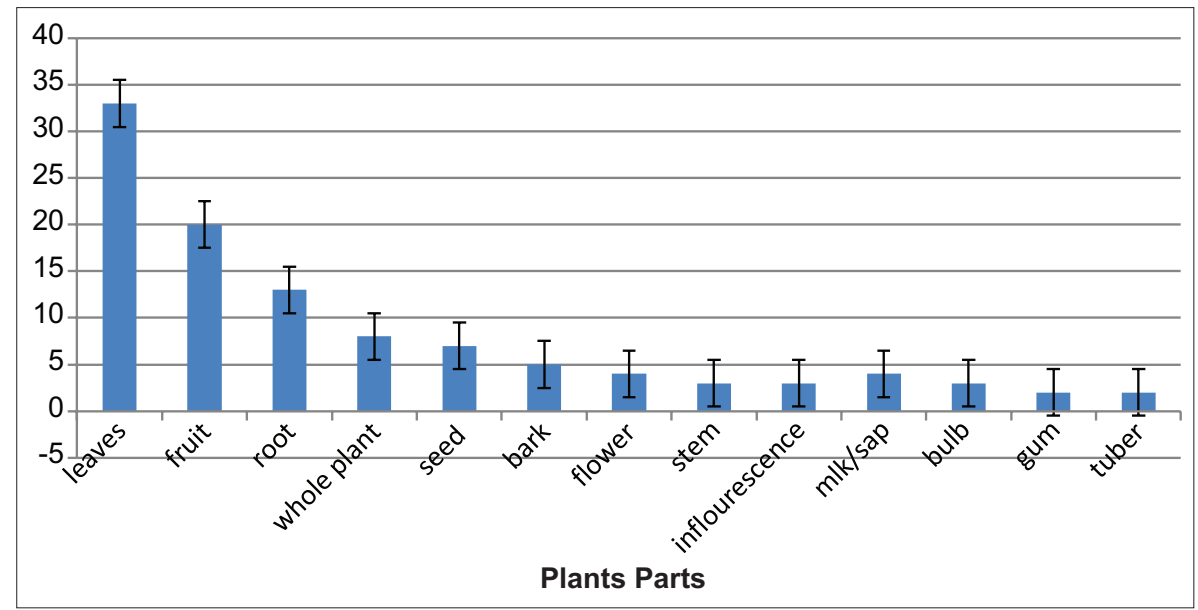

Figure 4: Percentage of plants used 
Table 4: Percentage of species and citations in each medicinal use category

\begin{tabular}{|c|c|c|c|c|c|c|}
\hline S no. & Disease category & $\begin{array}{l}\text { No of use } \\
\text { reports }\end{array}$ & $\begin{array}{l}\text { \%age of } \\
\text { reports }\end{array}$ & $\begin{array}{c}\text { No } \\
\text { ofspecies }\end{array}$ & $\begin{array}{l}\text { \%age of } \\
\text { taxa used }\end{array}$ & $\begin{array}{l}\text { Informants consensus } \\
\text { factor (ICF) }\end{array}$ \\
\hline 1 & Jaundice, Wounds, Back pain, Skin disease, & 2 & 1 & 1 & 1 & 1.0 \\
\hline 2 & Dissolving kidney, Urinary bladder Food, Stones, Flushing urinary blocks & 34 & 18 & 18 & 12 & 0.39 \\
\hline 3 & Delivery, Dandelion wine, Constipation,Fever. & 17 & 16 & 9 & 11 & 0.07 \\
\hline 4 & $\begin{array}{l}\text { Worm infestation, constipation, Diuretic, } \\
\text { hand burning. Fever, Skin allergy }\end{array}$ & 14 & 13 & 7 & 9 & 0.08 \\
\hline 5 & Ear, nose and throat disease (ENT) Earche, throat inflammation, & 4 & 3 & 2 & 2 & 0 \\
\hline 6 & Jaundice/ Liver, Digestive, Fever, Ulcers, Cephalalgia & 18 & 16 & 9 & 11 & 0.12 \\
\hline 7 & Blood pressure, Stimulation, Aphrodisiac, Digestive & 7 & 5 & 4 & 3 & 0.34 \\
\hline 8 & Infectious disease (Malarial fever,typhoid,measles & 15 & 14 & 8 & 7 & 0.09 \\
\hline 9 & Bones fracture, dislocation, joints pain & 12 & 7 & 5 & 5 & 0.3 \\
\hline 10 & Skin disease, Chest Pan. hands burning & 9 & 8 & 6 & 6 & 0.14 \\
\hline 11 & Produces protein, Toothache, Narcotic, Aphrodisiac, Sprains, Fracture & 35 & 19 & 19 & 13 & 0.52 \\
\hline
\end{tabular}

Table 5: Fidelity level (FL) of medicinal plants of the study area

\begin{tabular}{|c|c|c|c|c|c|}
\hline S.no & Plants name & No of informants repoted the taxa & number of aliments treated & No. of use frequently determined by informant & $\mathrm{FL}$ \\
\hline 1 & Berberis lyceum & 16 & 4 & 16 & 100 \\
\hline 2 & Bergenia ciliata & 34 & 5 & 38 & 86.48 \\
\hline 3 & Coriandrum sativum & 25 & 4 & 25 & 100 \\
\hline 4 & Momordica charanita & 36 & 5 & 36 & 100 \\
\hline 5 & Cuscuta reflexa & 10 & 3 & 18 & 55.56 \\
\hline 5 & Cedrus deodara & 17 & 3 & 22 & 77.28 \\
\hline 7 & Cinnamomum tamala & 25 & 2 & 25 & 100 \\
\hline 8 & Equisetum debile & 13 & 3 & 13 & 93.67 \\
\hline 9 & Luffa cylindrica & 20 & 4 & 29 & 98.97 \\
\hline 10 & Lathyrus aphaca & 26 & 2 & 18 & 69.24 \\
\hline 11 & Musa paradisiacal & 24 & 3 & 24 & 100 \\
\hline 12 & Punica granatum & 33 & 1 & 29 & 87.88 \\
\hline 13 & Persicaria amplexicaulis & 21 & 2 & 16 & 76.19 \\
\hline 14 & Phyllanthus emblica & 28 & 1 & 26 & 92.86 \\
\hline 15 & Rosa indica & 20 & 2 & 18 & 90 \\
\hline 16 & Ricinum communis & 29 & 2 & 24 & 82.76 \\
\hline 17 & Trichosanthes cucumerina & 12 & 2 & 11 & 91.67 \\
\hline 18 & Taraxacum officinal & 24 & 2 & 21 & 87.17 \\
\hline 19 & Vitis jacquemontii & 15 & 1 & 8 & 53.34 \\
\hline 20 & Zanthoxylem armatum & 26 & 3 & 26 & 100 \\
\hline 21 & Zee mays & 28 & 2 & 28 & 100 \\
\hline
\end{tabular}

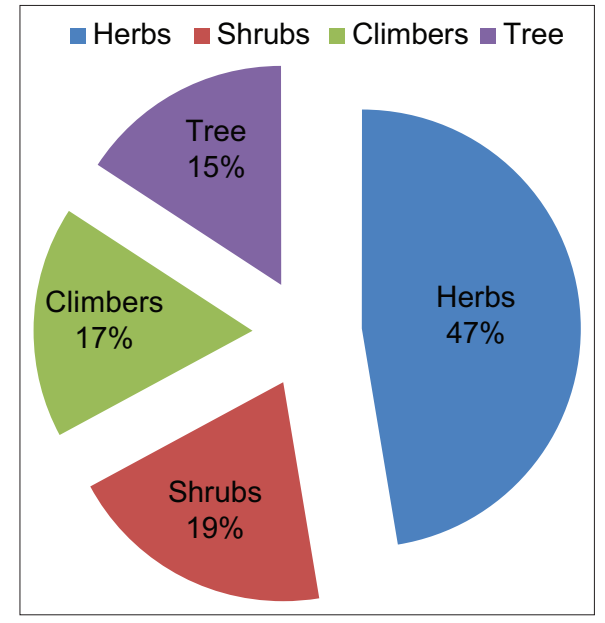

Figure 5: Percentage of plant life form

\section{CONCLUSION}

This study first documented the information about the traditional medicinal plants in Pir Panjal range in Jammu division Himalaya of Union territory Jammu \& Kashmir-India. The area is rich in medicinal plants and these plants are still commonly used for medicinal purpose of people in their daily lives. There is a gradual loss of traditional knowledge about these medicinal plants in new generation. Thus it is felt important to document and reconstitute the remainders of the ancient medical practice which exist in the area as well as other part of the region and Preserve this knowledge for future generation. This data matches with that of Singh and Kirn. [28] provide a list of some alpine plants of Poonch; Kirn [28] presented a brief account of some medicinal plants of Pir Panjal range: Singh [29] gave an introductory account of some wild flowering plants of Rajouri; Vir Jee et al. [30] reported their concise taxa-ethnobotanical observation made in some rural areas of Rajouri. Thus, such type of study may also bring to light some new source of drugs for control the disease. This study also provides basic for the conservation of the local flora; It will also provide various socio-economic dimensions associated with the common people.

\section{ACKNOWLEDGEMENTS}

This research was carried out in Centre for Biodiversity Studies, School of Biosciences and Biotechnology Baba Ghulam 
Shah Badshah University, Rajouri. I am thankful to the Vice Chancellor, Professor Javed Musarrat for believing me and giving me opportunity to serve as Extension Scientist in Centre for Biodiversity Studies. I would like to place on record my sincere gratitude to my mentor, Professor, Iqbal Parwez Dean School of Biosciences and Biotechnology for his guidance, constant support and motivations, Without his help this work would not have been possible.

\section{REFERENCES}

1. Redzić, S. S. 2007. The ecological aspect of ethnobotany and ethnopharmacology of population in Bosnia and Herzegovina. Collegium Antropologicum. 31; 869-890

2. Ullah, R., Hussain, Z., Iqbal, Z., Hussain, J., Khan, N., Muhammad, Z.., Ayaz., Z., Ahmad, S., 2010.Traditional uses of medicinal plants in Dara Adam Khel NWFP Pakistan. Journal of Medicinal Research, 17: 1815-1821.

3. Safa, O., Soltanipoor, M.A., Rastegar, S., Kazami, M., Dehkord, K.N., Ghannadi, A., 2012. An ethnobotanical survey on Harmozgan Province, Iran. Avicenna Journal of Phytomedicine, 3(1): 64-81.

4. Nasab, K.F., Khosravi, A.R. 2014.Ethnobotanical study of medicinal plants of Sirjan in Kerman Province, Iran. Journal of Ethnopharmacology, 154; 190-197

5. Singh, H., Husain, T., Agnihotri, P., Pande, P.C., Khatoon, S. 2014.An ethnobotanical study of medicinal plants used in scared groves of Kumaon Himalaya. Uttarakhand. Iran Journal of Ethnopharmacology, 154; 98-108.

6. Hamayun, M., Khan. M.A. and Hayat, T., 2005. Ethnobotanical profile of Utror and Gabral Valleys, District Swat,Pakistan.www.ethnoleaflets. com/leaflets/swat.htm.

7. Shah, A., Abass, G., Sharma MP. 2012. Ethnomedicinal study of Some Medicinal plants from Tehsil Budhal, District Rajouri Jammu and Kashmir. International Multidisciplinary Research Journal, 2(6); 05-06

8. Mahmood, T., Shah, A., 2012. Medicinal plants used by traditional healers in Poonch district of Jammu and Kashmir, Life Science Leaflets. 5: 53-60.

9. Mahmood, T., Kadam, D., 2012. Some medicinal Plants used for the treatment of Jaundice and Hepatitis based on Tribal and rural people of Poonch \& Rajouri Jammu and Kashmir. Environment and Ecology, 3:449-454

10. Mahmood, T., 2019. A report on ethnomedicinal Plants used by Gujjar - Bakarwal tribes of Some Parts of Pir Panjal Himalayas of District Rajouri Jammu and Kashmir India. Environment and Ecology, 37(1A); 293-303.

11. Mahmood, T., 2019. Ethnomedicinal study of useful climbers creepers and twiners of Baba Ghulam Shah Badshah University campus and adjoining areas of District Rajouri (Jammu and Kashmir). Med. Aromatic Plants (Loss Angles), Vol.8 Iss.6 No.8:340.doi:10.35248 2167-0412-19. 8.340

12. Pant, S., Verma, S., 2008. Ethnomedicinal notes on Tree Species of Pir Panjal Biodiversity Park of Baba Ghulam Shah Badshah University Rajouri, Jammu and Kashmir, India. Ethnomedicinal Leaflets, 12:404-412.
13. Malik, A.H, Khuroo, A.A., Dar, G.,H., Khan, Z., S. 2010.The woody flora of Jammu and Kashmir India. An updated Checklist. Journal of Economic and Taxonomic Botany, 34(2): 274-297.

14. Shah, A., Bharati, K.A., Ahmad, J., Sharma, M.P. 2015. New ethnomedicinal claims from Gujjar-Bakarwal tribes of rajouri and poonch districts of Jammu and Kashmir, India. Journal of Ethnopharmacology, 166: 119-28.

15. Dar, G.H. Akhter.,H, Malik and Anzar., A. Khuroo. 2014. A contribution flora of Rajouri and Poonch District in the Pir Panjal Himalaya Jammu and Kashmir,India.www.checklist.org.br

16. Sharma, B.M and Kachroo, P.1981-82. Flora of jammu and plants of Neighbourhood.Vols.I-II. Bishen Singh Mahendra Pal Singh, Dehra Dun, India

17. Bibi,T., Ahmad, M., Tareen, B.R.,Tareen, M.N., Jabeen, R., Rehman, Ur R., Sultana, S., Zafar, M., Yaseen, G., (2014) Ethnobotany of medicinal plants in district Mastung of Balochistan province Pakistan. Journal of Ethnopharmacology, 79-89.

18. Jain., S.K., Rao. R.R., 1977.A Handbook of field and herbarium Methods. Today and Tomorrow Printers and Publishers, New Delhi.

19. Polunin, O, and A. Stainton. 1986. Flowers of the Himalaya, $2^{\text {nd }}$ reprint Oxford University Press, Delhi, Bombay, Calcutta \& Madras.

20. Shabana A., G. H. Dar and A. Q. Jhon. 2013. Exotic Ornamental Flora of Kashmir: A Field Guide. Dominant Publishers \& Distributors Pvt. Ltd., New Delhi, India.

21. Hooker, J.D. 1872-97. The flora of British India. Vols I-VII. London: L. Reeve and Co.

22. Trotter, R.T., Logan, M.H., 1986.Informants consensus; a new approach for identifying potentially effective medicinal plants, In Etkin, N.L. (Ed.).Plants in indigenous Medicine and Diet. Redgrave Publishing Company, Bedford Hills, New York, pp. 91-112

23. Gazzaneo, L., R.S., Lucena, R.F.P. Albuquerque. U.P., 2005. Knowledge and use of medicinal plants by the local specialists in a region of Atlantic forest in the state of Pernambuco (North eastern Brazil). Journal of Ethnomedicines, $1 ; 1-11$

24. Friedman, J., Yaniv, Z., Dafni., A., Palewitch, D., 1986.A preliminary classification of the healing potential of medicinal plants, based on the rational analysis of an ethnopharmacology field survey among Bedouins in Negev Desert, Israel. Journal of Ethnopharmacology, 16 : 275-287.

25. Gurdal, B., Kultur, S., 2013. An ethnobotanical study of medicinal plants in Marmaris (Mugla, Turkey). Journal of Ethnopharmacology, 146.113-126.

26. Ahmad, M., Shazia, S., Fazl., Hadi, S., Hadda.T.B., Rashid, S., Zafar, M., Khan, M.A,. Khan, M.P.Z., Yaseen, G. 2014. An ethnobotanical study of medicinal plants in high mountainous region of Chail valley (District Swat-Pakistan). Journal of Ethnobiology and Ethnomedicines, 10 1-36.

27. Jamila, F., Mostafa. E. 2014. Ethnobotanical survey of medicinal plants used by people in Oriental Morocco to manage various ailments. Journal of Ethnopharmacology, 154:76-87.

28. Kirn., H.S. 1992. Pir Panjal Range, a paradise of medicinal plants; pp.63-65,in: M. P. Sharma (ed.).Bahar-e-Rajouri-92.Nehru Yuva Kendra Rajouri

29. Singh, H., 1992. Wild flowers of Rajouri mountains; PP.60-62.,in:M.P. Sharma (ed.). Bahar-e-Rajouri-92. Nehru yuva Kendra, Rajouri

30. Vir Jee, Dar G.H, P, Kachroo and G. M. Bhat. 1984. Taxo-ethnobotanical Studies of the rural areas in district Rajouri (Jammu). Journal of Economic and Taxonomic Botany 5 (4): 831-838. 